\title{
Barack Obama Meets Celebrity Metaphor
}

\author{
Jeffrey C. Alexander
}

Published online: 30 July 2010

(C) Springer Science+Business Media, LLC 2010

\begin{abstract}
Common knowledge suggests that elections are won or lost based on demographics, finances, and other structural elements. Whether candidates win or lose, however, is a matter of action. Symbolic identification, metaphor, and an unfolding narrative - and how they are managed and interpreted in the flow of events - determine who will emerge victorious from the democratic struggle for power. The McCain campaign's effort to cast Obama as a celebrity, with the hollow trivialities and self-aggrandizement of Paris Hilton and Britney Spears, proves to be one of the most dangerous episodes for the Obama campaign. In response, the Democrats must adjust the staging of Obama's Thursday night acceptance speech in Denver as a performance of purpose and gravitas, rather than glitz and adoration.
\end{abstract}

Keywords Elections, presidential · Obama, Barack · Celebrity $\cdot$ Metaphor $\cdot$ Power $\cdot$ Performance $\cdot$ Politics

In late June, 2008, Peggy Noonan made this prediction in her Wall Street Journal column: "The campaign will grind along until a series of sharp moments ... Things will move along, Mr. Obama in the lead. And then, in a just a few weeks out from the election, something will happen." The wily wordsmith of Reagan's presidency knows the democratic struggle for power is not determined by the structures of society. Only after its outcome is known do social scientists and pundits claim the contest was pre-determined to come out in this or that way. Certainly, the struggle for power is oriented to economic situations and cultural traditions, and other social formations as well, but it is not directed by them.

The democratic struggle for power is a matter of action, not structure. It is a flow, a stream of strategic decision and meaning-making. This coursing river hurtles steeply downward from the mountain top of the contest's beginning to the finish line in the valley below. Candidates feverishly ply their campaign ships along this fiercely churning current, struggling to keep direction, sometimes just to stay afloat. As they navigate the rushing water, giant boulders suddenly emerge, seemingly at random, blocking their path. The political skippers try desperately to maneuver around these looming impediments. Their efforts to do so mark the turning points of campaigns. The electoral stream divides, one branch rushes onward to triumphant victory, the other peters out to deflating defeat.

Three boulders emerged as the turning points in 2008: celebrity metaphor, Palin effect, and financial crisis. The first emerges toward the end of July and showers

J. C. Alexander $(\square)$

Yale University,

140 Prospect Street, P.O. Box 208265, New Haven, CT 06520-8265, USA

e-mail: jeffrey.alexander@yale.edu 
Public Opinion during the 2008 Presidential Election

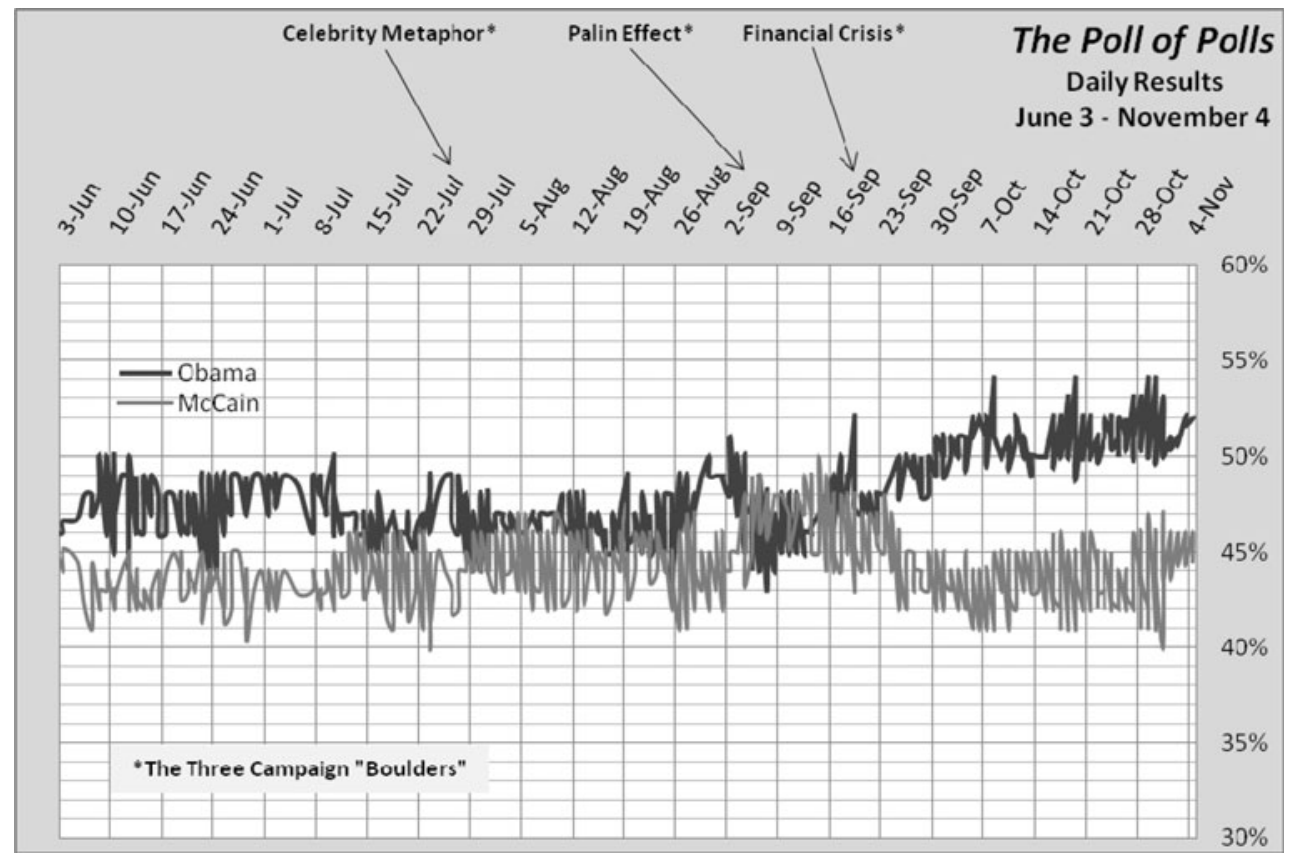

radioactive dust over the Democratic campaign until, five weeks later, Obama demonstrates his hero bona fides at his Denver convention speech. Immediately afterward, the newly hopeful Democratic campaign is knocked off balance again by the energy burst of Sarah Palin as she explodes on the national scene. Then, even as ship Obama succeeds in righting itself - the half-life of Palin effect is shorter than celebrity metaphor-the financial crisis looms suddenly like a giant iceberg threatening to capsize both campaigns. The Republican craft lists dangerously; the Democrats' hardly founders. By early October, the rushing stream of the election has divided, marking the effective end of the 2008 campaign, which voting confirms on November 4.

The democratic struggle for power is marked, in other words, by contingent moments where performative opportunities are seized, or lost. In early June 2008, the Wall Street Journal handicapped the Obama campaign.

Barack Obama has claimed the Democratic nomination, but he limped rather than sprinted to the end of the long primary season. Now his campaign must overcome the vulnerabilities ... The Illinois senator moves forward from the primaries after a string of losses, a rocky breakup with his longtime church, and an apparent weakness in attracting the white, working-class demographic seen as crucial to a democratic victory in November ... Sen. Obama's [primary] losses [to Hillary Clinton] in Ohio and Pennsylvania have some people wondering if the candidate will face difficulty in connecting to voters in these key states in November ... A Quinnipiac University poll of likely voters released May 20 shows Sen. McCain defeating Sen. Obama in two of the three major swing states: Florida, Ohio and Pennsylvania.

In the months following this prediction that the demographic conditions are stacked against Obama, the Democratic candidate performs in a masterly political manner. He subtly works the binary discourse of civil society and carefully connects it with gender, religion, and race. He continues to represent himself in the collective imagination as a transformative figure, a hero who can resolve the crisis of our time.

McCain, meanwhile, stumbles badly. Only one month after the Journal describes Obama's imposing post-primary hurdles, the paper reports with alarm "the blurry, oftenconflicting signals Sen. McCain had been sending voters." Acknowledging that "controlling the message of a candidate is tricky for any campaign," the Journal suggests, nonetheless, that "it seems to be a particular challenge for Sen. McCain." The Republican's "message is fractured," his campaign events "thrown together with little more than a flag and a microphone." When he tries reading from teleprompters, he seems wooden and fake. When he tries for spontaneity, he seems confused-when he "speaks off the cuff and strays from his script," the campaign veers dangerously "off-message." 
Here is the paradox of performative politics. To avoid seeming ridiculous, to regain authenticity, McCain must become more self-conscious and skillful in presenting his image. In his New York Times column, neo-conservative guru William Kristol observes that so far-in June and early July- "Obama has achieved the important feat of seeming an increasingly plausible president," while McCain has managed to seem "less plausible." The problem is not with the actual candidate, from Kristol's point of view, but with the symbolic framework containing him. Kristol bemoans that the "campaign has failed to develop an overarching message." To regain McCain's authority and popularity, the Republican campaign "desperately needs a message and a narrative," one that is "appropriate for the candidate and for the times." It has become overwhelmingly clear to conservative political strategists that McCain cannot be left to his own devices. He must be taken in hand. Kristol suggests that Republicans bring back Mike Murphy, describing the veteran conservative consultant as a "creative" tactician and an "imaginative ad maker." Murphy's "great skill has always been an ability to find a clear theme for his candidates." The title for Kristol's column is "Where's Murphy?"

The McCain campaign knows it needs a make-over, but the job of directing the operation is given to someone else. As the Wall Street Journal reports, it is Steven Schmidt who will be put in charge of sculpting and controlling the image of John McCain. Explaining that "Mr. Schmidt runs his teams with an almost military style of discipline," the paper offers conservatives reassurance: "He thinks in bullet points ... and is impossible to move off message."

\section{Glimmer from the Dark Side}

Yet, as August approaches, the McCain campaign is struggling still. Barack Obama has just launched an unprecedented foreign trip for 10 days in late July, strategically repositioning himself before the general election campaign. Jetting from Iraq and Afghanistan to Israel, Berlin, Paris, and London, Obama is greeted by cheering foreign crowds, plays hoops with grinning American soldiers and sinks a jump shot from 40 feet, and is accorded the deference and publicity normally due heads of state. The success of Obama's excursion threatens to take foreign affairs off the table, a development that would be devastating to the McCain campaign. If the Republican can't play the role of military hero with greater command of foreign policy, he will have to go negative and shift a harsh spotlight on Obama himself.

There is, in fact, one sliver of hope that Republicans find in Obama's triumphant odyssey, and it is a glimmer from the dark side. Every hero has a shadow. If Obama can be convicted of hubris, of being arrogant and aloof, Republicans may still block his heroic ascent, and make him seem anti-democratic besides. What follows is a New York Times account of a secret Republican strategy meeting that took place in late July.

"Gentlemen, let me put a few things on the table for observation and discussion," Steve Schmidt said to his fellow strategists while sitting in a conference room in the Phoenix Ritz-Carlton. "Would anyone here disagree with the premise that we are not winning this campaign?"

No one disagreed. It was Sunday, July 27, and Obama had just concluded an eight-day swing through the Middle East and Europe that received practically round-the-clock media coverage. "Would anyone disagree with the premise," Schmidt went on, "that Mr. Obama has scored the most successful week in this entire campaign? I mean, they treated him like he was a head of state! So tell me, gentlemen: how do we turn this negative into a positive?"

"It's third and nine," Bill McInturff, a pollster, observed. "Time to start throwing the ball down field."

Eventually, it was Schmidt who blurted out the epiphany concerning Obama. "Face it, gentlemen," he said. "He's being treated like a celebrity."

The others grasped the concept - a celebrity like J-Lo! Or Britney! - and exultation overtook the room.

Schmidt's revelation marks an extraordinary moment of aesthetic discovery, creating a trope that will upend the Obama campaign. When metaphors work, they clarify conflicting feeling and understanding. The mainstream liberal press admires Obama's foreign adventure, and European crowds love him, but for conservatives who see him in terms of darker, anti-civil qualities, and moderates who might still be convinced to do so, this adulation seems patently undeserved.

As Obama's foreign quest unfolds, conservative media and pundits move to separate his heroic image from his mundane person, making the person seem fake and the performance staged. The Democrat frames his foreign visit as a "fact finding" tour, but his critics call this a ruse. As Obama meets with military and political leaders in the middle east, conservative politico and former UN Ambassador John Bolton asserts on Fox, on July 21, that Obama "had his mind made up on Afghanistan and Iraq before he went," that rather than being independent and open-minded, "he's simply repeating the mantra of the last few years." The next day, Murdoch's New York Post agrees, informing its readers Obama has "already made his decisions," that his intention is merely "to flash 
through" hotspots so he can make a show of solving problems "that have stymied peace-makers for years." Fox's Sean Hannity describes the trip as a "photo-op," giving it high marks only for being "well choreographed." The veteran conservative journalist Fred Barnes lauds Obama's "stagecraft" as "tremendous," sarcastically acknowledging that the "TV shots ... and some of the newspaper pictures - with Obama in the helicopter-looked great."

If Obama's foreign trip is merely an outrageously staged performance, why is it hailed on all sides as a powerful success? For Obama's conservative opponents, it can only be the messengers, not the members of the citizen-audience, who are to blame. With the trip still in its early days, an analyst for conservative Media Research Center lashes out at "Obama's magical media tour." In a website video entitled "Obama Love 3.0," the McCain campaign replays enthralled comments by reporters against the background music, "Can't Take My Eyes Off of You," a Fox pundit later explaining "the campaign is going with the Frankie Valli song" because "of how much the media loved Obama." The ultra-conservative Washington Times complains of "adoring press coverage Elvis would envy," of the press having "crowned" Obama "as the permanent American Idol."

From the conservative point of view, there is not only a media but a moral question here. Obama is being deified in a Judeo-Christian civilization that is dead set against idol worship. "There was more worship of Obama on this trip than occurs in an average church on Sunday morning," conservative columnist Cal Thomas fulminates on Fox at the end of Obama's trip. "I've never seen anything like it," Thomas exclaims. It was "messianic and unbelievable." Fred Barnes declares the trip "breathtakingly presumptuous." The conservative strategist Karl Rove observes the foreign adventure "bespoke a little bit of brashness and arrogance." Far from being pure and heroic, the Obama image is shadowed and threatening. The Democratic candidate stands accused of hubris on a grand scale. Can he be made to appear guilty as accused?

\section{The Advertisement}

This question is answered, symbolically not factually, two days after Obama returns from Europe, on July $29^{\text {th }}$. That evening, McCain's campaign places a 30 second advertisement on its website that calls out Obama as a "celebrity." The next day, the advertisement runs nationally on cable and locally in eleven battleground states, and over the next week, it's "played endlessly on news channels" and draws "millions of hits on YouTube." The ad begins with a powerful, slightly blurred tracking shot of the enormous German crowd that gathers for Obama's speech in Berlin. Seconds later, muffled chants of "O-ba-ma! O-ba-ma!
O-ba-ma!" roll rather ominously from the screen. With the chanting in background, flash bulb lights pop brightly, Britney Spears and Paris Hilton are glimpsed in famous poses, and a grinning Barack Obama appears on the screen addressing the massive crowd. He stands before a tilting Victory Arch in Berlin, his image grainy as if in an old newsreel. A baritone voice-over intones gravely, "He's the biggest celebrity in the world, but is he ready to lead?"

At first, skeptical observers on both sides of the ideological spectrum reject out of hand the idea that this most serious, ambitious, and moralistic of contemporary political figures is a celebrity. Evaluating it empirically, they declare it to be false, an outrageous distortion of factual reality. One contributor to ABC's Good Morning America advises "you wanna [sic] draw contrasts between yourself and your opponent, but you want voters to see that as valuable contrasting information rather than simply as name calling." National Pubic Radio interviews an academic expert on negative campaigning, asking "What do you make of this McCain ad which aims to draw a comparison between Obama and Paris Hilton and Britney Spears? Will people buy that?" The professor answers, "I suspect not," explaining, "I don't think it's a very good ad" because, while not "incorrect or factually inaccurate, per se ... it strikes me as a stretch." NBC luminary Tom Brokaw confronts McCain friend and campaign surrogate Senator Joseph Lieberman with the same factual query: "What does [Obama] have to do with Paris Hilton or Britney Spears?" Even the entertainment journalists on Showbiz Tonight are having nothing to do with it. "It first broke on Wednesday," comments co-host A.J. Hammer, and "quite frankly, it was just plain ridiculous." Guest Jane VelezMitchell immediately agrees.

It's so shocking ... John McCain should not be comparing Obama to any actors whatsoever, but especially not Britney Spears. That is so over the top. Let's remember, Britney Spears is a woman who was rushed on a stretcher into a psych ward and committed for several days until her father was given conservatorship over her affairs because she was deemed to be incompetent of [sic] taking care of herself. And that's the person that McCain is comparing Obama to? This is absolutely outrageous.

In response to such moralistic criticism of factual content, McCain protests that the celebrity ad should not be taken so seriously. "We're having some fun," the Republican protests, chiding his overly literal critics. His Communication Director tells another reporter it's just "a very fun, light-hearted ad." Taking such empiricist criticism to its logical conclusion, the Wall Street Journal reports, on August 1, that "the celebrity link was a leap that fell flat."

But it did nothing of the kind. Months later, in the middle of October, the Journal will implicitly acknowledge 
its error, writing that "a deft ad, like McCain's spot questioning the substance behind Obama's extraordinary celebrity, still can get an opponent reeling." In fact, the paper now places the celebrity campaign into the pantheon of political advertising alongside LBJ's 1964 "daisy ad" against Goldwater's nuclear policies and George H.W. Bush's 1988 Willie Horton campaign against the hapless Democratic candidate Michael Dukakis.

The critics were wrong to dismiss the advertisement's importance, reasoning from empirical inaccuracy to limited political effect. It is the symbolic power of the celebrity advertisement that matters, not its factual accuracy. Its authority is performative, its cultural power immediately felt. Up to this point, accusations about Obama's hubris have been suggestive, general, and atmospheric, offering analogies such as Obama is "looking like a rock star." With its newly confident and sober verbal identification of Obama as a celebrity, and its iconic visualization, the new advertisement makes these atmospherics concrete. The idea of hubris is no longer a matter of making two different things seem similar. It becomes, instead, a statement about one thing. Obama is not like a celebrity, he is one. In place of simile, there is metaphor. Prescription becomes description, an admixture of qualities becomes a single compound. The Washington Times describes the ad as "stark, harsh and groundbreaking." This gets its metaphoric power just right.

Celebrity metaphor creates a new cultural playing field. "Do the American people want to elect the world's biggest celebrity or do they want to elect an American hero?" Steve Schmidt asks reporters as he announces the roll-out of the ad campaign. The Republicans' cunning and brilliant new image maker presents Obama's celebrity as if it were an indisputable fact, one that, on its face, disqualifies the Democrat from occupying the hero position in the campaign. When Obama protests the ad's accuracy, Republicans rise above the factual level to narrative reality. "Like most celebrities," a campaign spokesman suggests, Obama "reacts to fair criticisms with a mix of fussiness and hysteria." Campaign manager Rick Davis responds to questions about the advertisement's accuracy in the same way: "Only celebrities like Barack Obama go to the gym three times a day, demand MET-RX chocolate roasted-peanut protein bars and bottles of hard to find organic brew-Black Forrest Berry Honest Tea-and worry about the price of arugula." Karl Rove suggests that, "in politics, when you get that kind of hubris," you must expect such criticism. He portrays Obama's fall as caused by the natural laws of politics, not by partisan feeling: "[Y]ou know, those whom the gods destroy, they first make prideful, and he's getting a little prideful." Today Show host Matt Lauer asks Republican senior strategist Nicole Wallace, Steven Schmidt's partner, whether the celebrity advertisement is "demeaning." Wallace declares it's not a matter of moral judgment but objective fact.

This ad is in some ways a celebration of his celebrity. I mean, I don't think there's much to debate this morning about whether he is or is not a celebrity. The $\mathrm{ad} . .$. makes a very serious and sober point ... We've never made jokes about Paris Hilton .... and look, I don't think we're making a joke of Senator Obama and neither were the 200,000 Germans who were there to celebrate his celebrity ... No one can forget or overlook or obscure the fact that Barack Obama is the celebrity in this contest and Senator John McCain, an American hero, is the underdog."

While the pleasures derived from this metaphorical eruption are partisan, the symbolic reality of the new playing field cannot easily be disputed by the Democratic side. Celebrity metaphor clarifies conflicting lines of conjecture and emotion, reducing anxiety and eliminating confusion, seeming to offer new hope, not only to frustrated conservatives but to muddling citizens in the middle of the fight. On the very evening it is placed on the Republican campaign website - before its nationwide distribution the next day - the ad's attention-getting power reveals itself when long-time Democratic advisor Susan Estrich refers to the already "widely talked about McCain ad that blasts Obama." The day after it is placed in circulation, CBS evening news anchor Katie Couric highlights what she already describes as "the nowinfamous McCain ad." Celebrity metaphor has fingersnapping, clutter-reducing, breath-in-taking impact. It is a matter of experience, not cogitation, providing an "ahaa!" moment for many. That evening, on World News, ABC anchor Charles Gibson observes, "some think McCain may have struck a cord (sic)." As the celebrity metaphor moves from mundane fact to dizzying symbol, a panelist on CNN's Showbiz Tonight observes, "[T]his is one of those moments that's taking on a life of its own." For Republicans, the air is filled with the sweet smell of performative success. One week after the ad's introduction, former Senate Majority leader Tom Daschle, political mentor to Obama, reluctantly acknowledges to the Financial Times that "the ad looks like it's working."

\section{Celebrity Pollution}

John Broder covered the campaign for the New York Times. He remembers the "celebrity effect" as a "pretty good trick," recalling "it certainly seemed to succeed in taking the gloss off" of Obama's foreign trip.

All of us sort of [were] swept up in the idea that [Obama] could draw 200, 300,000 people in a foreign 
capital - this was Kennedy-esque in the extreme, and they, the McCain people, were quickly able to turn that into a negative. That trip suddenly became sort of cancelled out. It was supposed to show his moda vitas and his ability to represent the country in the Middle East and Europe, and suddenly it was something that was no longer talked about.

The symbolic pollution that celebrity metaphor triggers now enters into the media mainstream. On July 30, number ten on late night talk show host David Letterman's famous Top Ten list is a "proposed bill to change Oklahoma to Okla-bama." Fox News' Brit Hume reports the incident, commenting that "when the late night comics start talking about something, you know it's getting in the bloodstream." ABC's celebrated journalist Diane Sawyer describes the Republican evocation of Britney Spears and Paris Hilton as having the force of a "political nuclear attack." $\mathrm{ABC}$ journalist Jake Tapper fulsomely elaborates upon the advertisement's claims: "Well, the McCain campaign thinks they have an effective line of attack against Senator Barack Obama, that he is an arrogant, arugula-eating, fancy berry tea drinking celebrity ... akin to Britney Spears and Paris Hilton, pretty, pampered, not up for being president." Senior ABC editor Michelle Cottle explains, "Americans don't like presidents who think they're better than the average guy." On the Republican campaign web site, staffers set up an "Audacity Watch."

In their democratic role as carriers of civic virtue, Americans are deeply suspicious of celebrity, contrasting narcissistic publicity seeking with true public spiritedness and polluting pseudo-fame as selfish and manipulative. For the left, celebrity is the dangerous product of an unbridled capitalism in which, as Andy Warhol once remarked, "Everybody is entitled to their fifteen minutes of fame." For the right, celebrity is the product of a degenerate modernity where, as one conservative columnist puts it, "America's stoic traditional culture" is being replaced by "hedonism, relativism, and self-indulgence." These shared republican (small " $\mathrm{r}$ ") convictions serve as cultural background for celebrity metaphor. What triggers the epiphany is connecting this signifier to Obama at a heated, anxious, and confusing moment in the campaign. For a statistically significant segment of the American electorate's muddling middle, the metaphor not only defines retrospectively Obama's foreign adventure but the content of his character in a prospective way. On the day after the ad begins circulating, a man from Clintonville, Wisconsin, makes this declaration to NPR's morning call-in show, Talk of the Nation.

I would just like to speak particularly to John McCain's most recent ad. But I have found this to be a characteristic of other negative ads. His is just, perhaps, the finest example that I have ever heard.
And when I speak of hear, I mean that the particular chant in the background of the ad - the Obama! Obama! Obama! - sort of smacks of chants that we have heard when we've seen images of dictators in a variety of foreign countries ... It's extremely disquieting, and unnerving, and really almost oppressive.

As the virus attaches itself to Obama's political DNA, celebrity emerges as one of the most damaging epithets of the campaign. A guest host on the liberal MSNBC cable news channel declares: "50 years ago, the charge being hurled around that would hurt any candidate was, you know, 'communist sympathizer.' There's another ' $\mathrm{C}$ ' word out there today, celebrity...He's a celebrity!"

\section{Reality Redefined}

Less than a week after the launch of celebrity metaphor, seven out of ten Americans have seen the original ad, and a slew of related children-of-celebrity ads, videos, counter-attacks, press releases, and campaign statements have appeared in the meantime. This statistic of seventy per cent records more than merely passive exposure. It suggests the energy that celebrity coding generates, how rapidly the narrative image circulates, how Americans have been drawn into the ad's symbolic meaning and are seeking it out. The ad cost less than $\$ 15,000$ to produce and no more than $\$ 200,000$ to air in the eleven battleground states nationwide. It is poetics not economic power that makes its performative success great. For the first time, McCain pulls even with Obama in the Gallup daily national tracking poll. Both candidates now register 44 percent, when just the week before Obama had a nine-point lead. A critical segment of the citizen-audience is not only watching but connecting with celebrity message, sensing verisimilitude, not construction, seeing its claim not as fiction but as truth. The New York Post reports the celebrity onslaught is having "far reaching effect," allowing McCain "to claw his way back." The Sunday Times describes the Democrats' "suddenly vulnerable Presidential campaign." The celebrity ad is the sixth most watched YouTube video of the week, McCain edging out Obama for seven straight days and eleven out of the last fourteen.

Republican momentum depends on keeping celebrity metaphor alive. Throughout August they succeed, but the ultimate test is the Democratic convention that comes at month's end. Can Republicans evoke celebrity trope to frame Obama's nomination? This is their aim.

\section{Fighting over the Stage}

For Democratic activists in the trenches, according to the New York Times, the "convention they had once anticipated would 
be a breezy celebration of Mr. Obama, had turned into a more sober and consequential event." As a former national Democratic chairman confides, "back in June and July, I truly thought he was going to blow McCain out of the water and carry 30 or 40 states," but "what has happened is that Republicans-McCain specifically - have really twisted his great charisma and this electric personality, to discredit his ability, his experience, his capacity, his judgment—I fear [what] they are about to do to him."

On Tuesday of convention week, the caustic and liberal New York Times columnist Maureen Dowd entitles her column "High Anxiety in the Mile-High City." Finding a "weird and jittery" vibe completely at odds "with the early thrilling, fairy dust feel of the Obama revolution," she attributes this symbolic deflation to the Republican celebrity campaign.

Democrats have begun internalizing the criticisms [of] John McCain about Obama's rock-star prowess, worrying that the Invesco Field extravaganza Thursday, with Bruce Springsteen and Bon Jovi, will just add to the celebrity cachet that Democrats have somehow been shamed into seeing as a negative .... "We're seeing a train wreck all over again," said one top Democrat.

With the convention imminent, conservative efforts to extend celebrity metaphor focus like a laser beam on Obama's Thursday night acceptance speech. Republicans know what is at stake. When Obama chooses to turn on the rhetorical throttle, he can display extraordinary dramatic force. His short speech at the 2004 convention triggered an immediate frenzy of excitement that catapulted him to national fame, even before being elected to the Senate. During his drive for the Presidency, crowds have flooded his speeches, seeming to become larger and more passionate with each passing week. The Republicans, then, have good reason to be afraid. But they also have cause for hope. If they can metaphorically frame Obama's acceptance speech as celebrity, none of his rhetorical skills will matter. The enormous crowd, the millions of television viewers, the frenzy, the transcendence, the passion-all of it will be polluted as hubris and artifice on the celebrity stage.

It is not so much the impending speech that draws the Republicans' critical attention. It is the physical settingthe actual stage upon which Obama will stand. In preparing his orations, Obama is a careful wordsmith, his rhetoric drawn from the civil religion's most time-honored phrases and themes. The jerrybuilt stage upon which he will deliver his convention speech is another matter entirely. It will be easier to interpret harshly, to place its meaning at an oblique angle to the earnest intentions of an idealistic AfricanAmerican politician. So it is the means of symbolic production, not the rhetorical symbols themselves, about which the Republicans choose to fight. Two months earlier, when celebrity was still a metaphor confined to Hollywood stars, the Obama campaign had decided to move the acceptance speech - the convention's concluding, most dramatic moment-away from the indoor intimacies of the convention hall to a giant outdoor football stadium seating upwards of 80,000 people. It seems like a good idea at the time. When the day arrives to deliver the speech, things have changed.

Democrats insist that the fluted columns, classical backdrop, and elevated dais are designed to evoke the White House and Lincoln Memorial. Conservative critics are having none of it. On the morning of the speech, the New York Post predicts that "Democrats will kneel before the 'Temple of Obama' tonight," evoking the celebrity ghosts haunting the Obama campaign in a concrete way. New York Post Washington Bureau Chief Charles Hurt suggests that Republican "lampooning of Obama's acceptance-speech stage as the 'Barackopolis' has created a genuine trap." It "may turn out to be one of the most fatal political mistakes in modern history," he predicts. That same morning, the New York Times reports Obama's aides are "feeling all the more pressure to bring a lofty candidate to ground level, showing Mr. Obama grasps the concerns of everyday Americans." Workers struggle up to the last minute to alter the physical setting of the speech. If they can tweak this material construction, its symbolic construction by critics and audiences might be more likely to go the Democrats' way.

On Wednesday, workers were still making changes to Invesco Field, home to the Denver Broncos, so it would feel more intimate, less like the boisterous rallies that served Mr. Obama so well early in the primaries, but also created the celebrity image that dogs him. They were still testing camera angles, so Mr. Obama would appear among the giant crowd, not above it. They took steps to reduce the echo effect, familiar to football fans, of speaking in such a cavernous space.

\section{Obama's Drama}

In the event, the fervent hopes of Republicans are frustrated and the fearsome anxieties of Democrats assuaged. The staged performances and audience reactions that fill up the afternoon and early evening at Invesco Field project sincere feelings and deeply patriotic principles, not artifice and celebrity. They create an expressive festival of community, belying the impression of a top down, rehearsed, directed-from-the top event. In its pre-convention issue, Time magazine has laid out the marks Obama performer must meet. 
A stadium's size is its message: it is the (literal) arena in which the audience connects individually to the man onstage and communally with the rest of the crowd. Like an arena rocker, Obama must make all listeners think he is speaking to each of them personally. And he has to reach a broad crowd, from the hipsters who think his early stuff was better to the mainstreamers just discovering him.

This is, in fact, exactly what the Democratic candidate achieved. Even some of Obama's most implacable conservative critics are persuaded that the Democrat might become a compelling collective representation of American democracy. The New York Post 's Washington Bureau Chief, he who had suggested the staging for Obama's speech might prove the most fatal political mistake in modern history, declares himself deeply impressed. "However the campaign turns out," Charles Hurt tells his conservative populist readers, "something very significant happened last night." His first person account is a hymn to democracy, the sentimental prose redolent with myth.

Thousands of people-far more than just the delegates to the convention-marched in lines stretching for miles under the searing Colorado sun to get here. They filled the arena from its grassy field to the mountain-top bleachers of Mile High Stadium... They were some 85,000 Americans, many attending their first-ever campaign event. They were young black kids with doo rags and very old white men. Men in suits with ties and teen girls wildly whipping little flags in the air. Hispanics in garishly sequined jeans and well-fed union guys. They were a mom who trudged up the impossibly vertical metal steps to the very tippy top of the stadium with a big baby strapped to her chest, a milk bottle in her hand and a backpack on her back. And for hours, they were transfixed. At times, it was a rock concert. At other times, it seemed like a great final sporting event. Or a religious revival. Yet what drew them all here was a political figure.

The fusion Obama hero has created causes celebrity metaphor to die.

Help from Hollywood is usually far more curse than blessing in American politics. But to dismiss last night as just so much celebrity would be very dangerous for Republicans. There was something else going on [and] it is mighty powerful, and John McCain could easily wind up on the losing end of it.

The morning after Obama's speech, Today Show host Matt Lauer asks Peggy Noonan, "So how did Barack
Obama do?" The former speech writer is in Denver, observing first hand. Lauder reminds Noonan: "Before the speech you wrote in The Wall Street Journal that you were unimpressed with the staging, the Greek column look, the hugeness of the arena." He then asks: "You were there with some 80,000 other people last night. Did you change your mind?"

Ms. NOONAN: I did a little bit. It—you could look at that staging, at the Athenian columns and - at the specific look of it and you could think, "Man, that's odd-looking," and you couldn't figure out how it connected to Obama. But by the end of that speech, I think I broke the code. At the end of the speech, Barack Obama spoke about Martin Luther King, 45 years before, speaking in front of the Lincoln Memorial with the beautiful columns behind him. And suddenly I realized that whole set was meant to be an evocation of Martin Luther King and his great speech that day .... and I think the set by the end had a certain glow to it. So I think at the end of the day it worked ...

LAUER: Let's talk a little bit more about content. Here's what you write in your column this morning ... "The speech itself lacked lift but had heft. It wasn't precisely long on hope, but I think it showed audacity. This was not smiling $\mathrm{O}$. He was not the charmer or the celebrity and he didn't try much humor. Mr. Obama often looked stern, and somewhat indignant." So if you were one of those people who's come to love those lofty hope-filled speeches, were you disappointed by this?

Ms. NOONAN: No, I don't think so. I think there was a certain science behind what Mr. Obama was doing. I think he was thinking, "Look, I'm going to have 30,35 , maybe even 40 million people watching me tonight. A lot of them have never seen me before. They've seen me from out of the side of their eye when they walk by a television, but they haven't really focused on me. I'm going to make them focus on me tonight but in a different way. I'm not going to be charming, lovely, vaguely humorous, interesting and expansive on the issues. I'm going to be a very serious, seriously adult person talking thoughtfully ..." ... Now in the past few weeks, John McCain's been giving him a few hard wallops. Obama has been holding his fire. All of a sudden in that speech last night he was not holding his fire. He was tough, he smacked him [McCain] around .... He was trying to ... steady the field there and even things up. 
LAUER: ... Let me end with history ... Did the speech, in your terms, live up to its historical significance?

Ms. NOONAN: They asked themselves to live up - to a lot when they put it in that big place. Did it live up to it? I think it was distinguished and memorable.
The half-life of celebrity metaphor was extraordinary, but it could not be stretched as far as the Republicans knew it must be. But if it came up short for conservatives, for the Democrats it was a nightmare that seemed to last a lifetime. Defeating the metaphor represented a lifeline for the Democratic campaign.

Public Opinion during Celebrity Metaphor Crisis

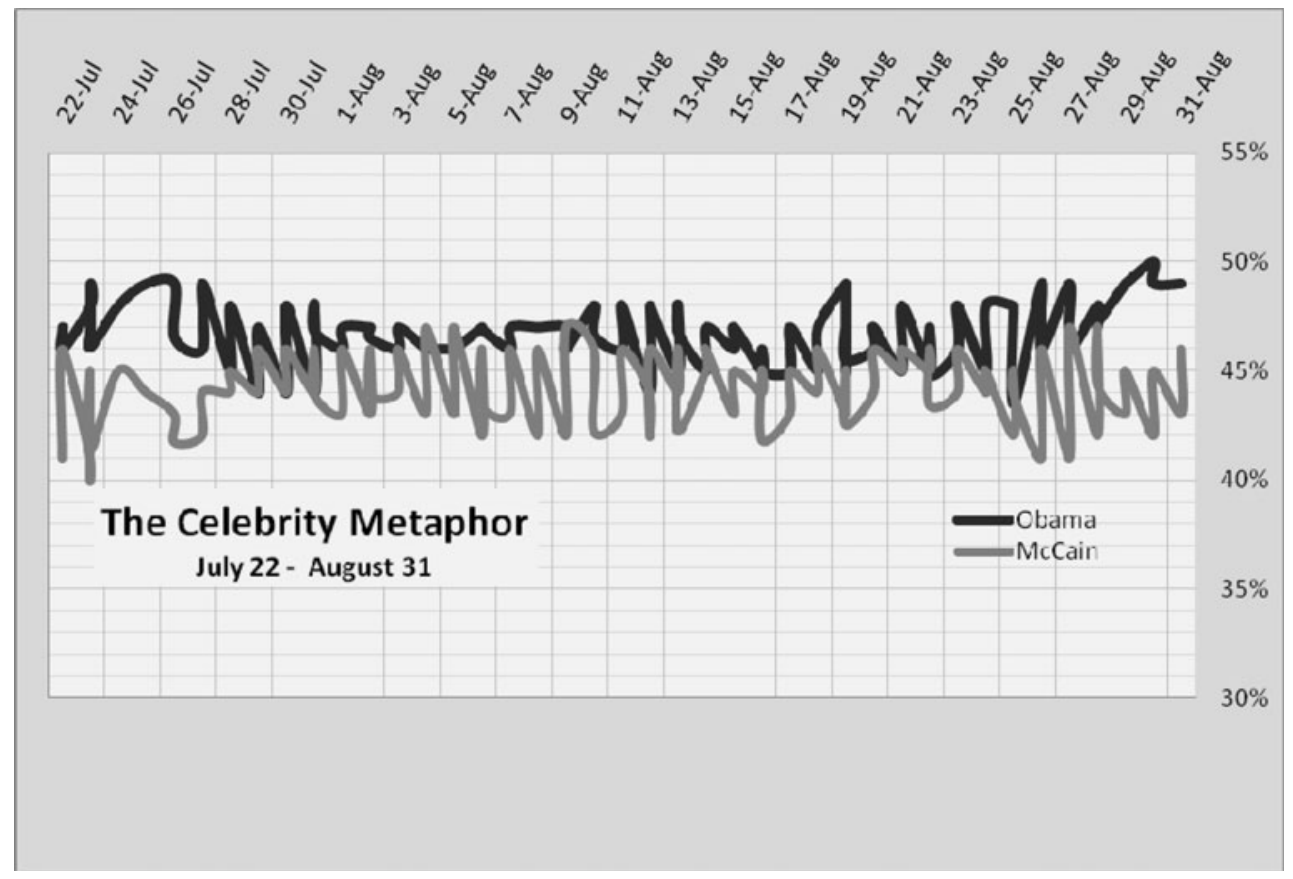

Jeffrey C. Alexander is the Lillian Chavenson Saden Professor and a Director of the Center for Cultural Sociology at Yale University. Among his recent books are The Civil Sphere (Oxford, 2006) and Remembering the Holocaust: A Debate (Oxford 2009). His most recent work is The Performance of Politics: Obama's Victory and the Democratic Struggle for Power (Oxford, 2010), from which the present article is drawn. 